Fakultas Hukum, Universitas Lampung, Bandar Lampung, Lampung, Indonesia. http:/ /jurnal.fh.unila.ac.id/index.php/corruptio

Volume 02 Issue 1, January-June 2021. PP: 45-60

P-ISSN: 2723-2573 E-ISSN: 2745-9276

\title{
Elements Testings Distortion of the Abuse of Authority Based on the Government Administration Law and Corruption Crime
}

\author{
Putri Nurmala Sari Siahaan \\ putrinurmalasaris@gmail.com
}

Universitas Indonesia, Indonesia.

Submitted: 01 February 2021; Reviewed: 15 March 2021; Accepted: 27 April 2021

\section{Article's Information}

Keywords: Elements; Testings; Distortion; Abue; Corruption.

\section{DOI:}

https://doi.org/10.25041/corruptio.v2i1.2246
Abstract

It is expected that the existence of the Government Administration Law is expected to be a solution so that there is no expression of "bad suspicion" against government officials in making decisions accused of causing losses to state finances. In addition, the GA Law is expected to become a reference for government officials in making decisions so that there is no abuse of authority. These two cargoes are a small part that is regulated in the GA Law. Regarding the abuse of authority itself, there have been specific regulations derived from the Supreme Court Regulation Number 4 of 2015 concerning Guidelines for Procedures in the Assessment of the Elements of Abuse of Authority. The problem that arises in examining the elements of abuse of power lies in the law enforcement process. The Perma Abuse of Authority states that the Court has the authority to accept, examine, and decide upon the appraisal request whether there is an abuse of authority in the Decisions and/or Actions of Government Officials before the criminal process. From the field facts, through case analysis, there are findings that government officials who submitted applications for the element of abuse of power did not heed the provisions in the Perma. In the two cases discussed, it 
appears that, in fact, the instrument of testing whether or not there is an element of abuse of authority is only used as an attempt to hide oneself from being ensnared from corruption. It is as if the petitioner has become a victim in the act of abuse of authority over the action or decision he has taken. However, the facts show otherwise where the applicant legally and convincingly committed a criminal act of corruption. It can be said that the use of the concept of testing the elements of abuse of authority is intended to be deviant and biased from the ideals of the concept.

\section{A. Introduction}

Many reports on public officials caught in corruption cases with allegations of abuse of power have become a scourge for other public officials to take any action or decision outside of the predetermined regulations. ${ }^{1}$ This can kill the creativity of public officials in carrying out their duties and functions and hinder the life of the bureaucracy. The elimination of expressions of criminalization against public officials is one of the reasons for the formation of Law Number 30 of 2014 concerning Government Administration (GA Law). From another point of view, the GA Law was formed to organize public officials not to act arbitrarily to harm the public or state finances. The problem of abuse of power is always related to discretion, ${ }^{2}$ Discretion often gets justification for actions that lead to corruption. Suppose there is a loss in state finance in the future due to decisions made through such discretionary steps. This has resulted in public officials fearing that their discretionary action will be considered a criminal act. ${ }^{3}$ This situation will create legal uncertainty in the field of state administrative action, namely between carrying out or taking action without a legal basis or neglecting an event for which a decision must be made immediately.

The presence of the GA Law is expected to be a two-sided solution to this problem. This solution is reflected in the suggestions in the results of the research "Criminalization of Public Official Policy" conducted by researchers from the Research and Development Center for Law and the Court of the Supreme Court Kumdil Education and Training Research and Development Agency. ${ }^{4}$ With the hope that the emergence of the GA Law can clarify the lines of authority and coordination between agencies, both within the circle of these agencies, horizontally and vertically, and facilitate understanding for law enforcers to minimize criminalization of state official policies. Regulations regarding the concept of abuse of power are contained in Articles 17-21 of Law Number 30 of 2014 concerning Government

\footnotetext{
1 Fransiska Adelina Sinaga, "BENTUK-BENTUK KORUPSI POLITIK ," Legislasi Indonesia 16, no. 01 (2019), https://e-jurnal.peraturan.go.id/index.php/jli/article/view/256.

2 Lutfil Ansori, "DISKRESI DAN PERTANGGUNGJAWABAN PEMERINTAH DALAM PENYELENGGARAAN PEMERINTAHAN," Jurnal Yuridis, vol. 2, August 25, 2015, https://doi.org/10.35586/.V2I1.165.

${ }^{3}$ Nur Kumalaningdyah, "Pertentangan Antara Diskresi Kebijakan Dengan Penyalahgunaan Wewenang Dalam Tindak Pidana Korupsi," Jurnal Hukum Ius Quia Iustum 26, no. 3 (September 1, 2019): 481, https://doi.org/10.20885/iustum.vol26.iss3.art3.

4 Muhammad Yasin. et.al., Anotasi UU Nomor 30 Tahun 2014 Tentang Administrasi Pemerintahan, (Uninversitas Indonesia : Center for Study of Governance and Administrative Reform (UI- CSAGR), 2017), pg. 51.
} 
Administration (GA Law). In the GA Law, abuse of authority is a genus, with 3 species, namely: (1) prohibition of exceeding authority; (2) prohibition of mixing up Authorities; and/or (3) prohibition of acting arbitrarily. Conceptually and theoretically, the division of the concept of abuse of power which the GA Law does not explain is inaccurate and misleading. ${ }^{5}$ This can open up opportunities to bend the implied meaning. Whereas in criminal law, namely the regulation of the concept of "abusing authority" contained in Law Number 31 of 1999 in conjunction with Law Number 20 of 2001 concerning the Eradication of Corruption (Corruption Law), explains that the concept is a species delict from the element of "against the law" (genus delict) which is always related to the public official. ${ }^{6}$ The regulation regarding the law enforcement process of abuse of power is currently specifically derived in the Supreme Court Regulation Number 4 of 2015 concerning Guidelines for Procedures in the Assessment of Elements of Abuse of Authority (Abuse of Authority Regulation). This regulation is the basis for the State Administrative Court or Peradilan Tata Usaha Negara (PTUN), ${ }^{7}$ To accept, examine, decide whether or not there is an element of abuse of authority requested by the Petitioner (Government Agency or Official who feels that their interests have been harmed by the results of supervision by the government internal supervision apparatus. ${ }^{8}$ Since the Perma Abuse of Authority issuance, several cases have been submitted to the Administrative Court. In this study, the author will only focus on the discussion of the case of Suryadharma Ali, the former Minister of Religion who filed his application at the Jakarta State Administrative Court with a request for whether or not there is an element of abuse of authority, Register Number: 250/P/PW/2015/PTUN-JKT, then the application is continued with a test of authority Number: 257/P/PW/2015/PTUN-JKT which was appealed to PTTUN Jakarta, Register Number: 110/B/2016/ PT.TUN.JKT. The following case that will be the object of this research is Andrey Dulu as Regional Secretary of East Borito Regency's tasks executor, Register Number: 15/P/PW/2016/PTUN.PLK.

The case mentioned above (Suryadharma Ali and Andrey Dulu) with a verdict that has committed a criminal act of corruption with the last decision at the re-filing (PK) level at the Supreme Court on the PK petition made by Suryadharma Ali with Decision Number 302PK/Pid.Sus/2018, which states: ${ }^{9}$

1. Reject the request for reconsideration from the Petitioner for Reconsideration / Convicted Suryadharma Ali;

2. $\quad$ To determine that the decision which is petitioned for reconsideration is still valid;

3. Charges the convict to pay the court fee at the review examination in the amount of Rp 2.500.00 (two thousand five hundred rupiahs)

Furthermore, the case that befell Andrey Dulu was the same that it was proven legally and convincingly guilty of committing the crime of corruption. From the two cases, it can be seen that there is a use of abusive element testing in the PTUN to avoid being caught in a

\footnotetext{
5 Muhammad Sahlan, "Unsur Menyalahgunakan Kewenangan Dalam Tindak Pidana Korupsi Sebagai Kompetensi Absolut Peradilan Administrasi," Jurnal Hukum IUS QUIA IUSTUM 23, no. 2 (April 17, 2016): 271-93, https://doi.org/10.20885/iustum.vol23.iss2.art6.

${ }^{6}$ Abdul Latif, Hukum Administrasi dalam Praktik Tindak Pidana Korupsi, (Jakarta: Prenada Media Grup, 2014), pg. 4.

7 Aju Putrijanti and Lapon Tukan Leonard, "Kompetensi Peratun Untuk Memeriksa Unsur Penyalahgunaan Wewenang," Jurnal IUS Kajian Hukum Dan Keadilan 7, no. 1 (April 23, 2019): 107-27, https://doi.org/10.29303/ius.v7i1.605.

8 Peraturan Pemerintah Nomor 4 Tahun 2015 Tentang Pedoman Beracara Dalam Penilaian Unsur Penyalahgunaan Wewenang (BN Nomor 1267 Tahun 2015), Pasal 3.

${ }^{9}$ Supreme Court Decision Number 302 PK/Pid.Sus /2018 regarding the verdict in the Surya Dharma Ali case, 22 April 2019, pg. 17.
} 
corruption case. The occurrence of abuse of authority in the principle of specialty (specialiteit beginsel) developed by Mariette Kobusen in her book entitled De Vrijheid Van De Overheid. ${ }^{10}$ This principle implies that each authority has a specific purpose. So if there is a deviation from this objective, it has the potential to give birth to acts of abuse of authority or often referred to as "deteornement de pouvoir". Testing of abuse of power is a complex problem because the concept of abuse of power is not only known in the study of state administrative law. There is a concept of abusing authority known in criminal law studies. For this reason, the scope concerning the interdisciplinary intersection of legal studies requires caution in the law enforcement process. This paper intends to discuss the concept of law enforcement contained in the Perma on abuse of power. In the Perma, the abuse of authority is the PTUN's power to accept, examine and decide upon requests for assessment of whether or not there is an abuse of power in decisions and/or actions of government officials before the criminal process, ${ }^{11}$ and after the results of supervision by the government internal control apparatus ${ }^{12}$. Therefore, the focus of the discussion in this study is how to test the application for assessment of abuse of authority based on the cases being studied and how paradigmatic testing of abuse of authority is under the aspirations of the GA Law. This research is more of a legal/normative research that places law as a norm system building regarding the principles, norms, principles of statutory regulations, court decisions, agreements, and doctrines (theories). ${ }^{13}$ It aims to solve legal problems that ultimately have benefits for the community and an improvement in the concept of law in the future.

Legal/normative research is carried out to produce new arguments, theories, or concepts to solve problems faced both theoretically and empirically. The expected answers in legal research are: right, appropriate, inappropriate, or wrong so that the results obtained already contain value through the statutory approach by examining all laws and regulations related to the legal issue being researched.

\section{B. Discussion}

\section{The Government and Corruption in the State Administration Law Perspective}

Power tends to corrupt, absolute power corrupts absolutely (Lord Acton), ${ }^{14}$ The adage that is still relevant today is those with the greatest potential for corruption: officials, state officials, and other stakeholders. Corruption is defined, explained, and discussed through various approaches. It can be seen from the barometer of elements of corruption which are not limited to aspects of integrity, aspects of state losses, aspects of fraud, and aspects of moral ethics. Corruption is an act against the law which is clearly against the mandate of the 1945 Constitution of the Republic of Indonesia and causes various kinds of disadvantages, including: ${ }^{15}$ weakening the nation's investment and economy, ${ }^{16}$ Raises inefficiency and

10 Satriya Nugraha, "KONSEP PENYALAHGUNAAN WEWENANG DALAM UNDANG-UNDANG TINDAK PIDANA KORUPSI DI INDONESIA," Sociosciientia 8, no. 1 (March 2016): 15-22, https://lldikti11.ristekdikti.go.id/jurnal/pdf/d3246e7b-3092-11e8-9030-54271eb90d3b/.

11 Government Regulation Number 4 of 2015 concerning Guidelines for Procedures in the Assessment of Elements of Abuse of Authority (Official Gazette Number 1267 of 2015), Article 2 paragraph (1).

12 Government Regulation Number 4 of 2015 concerning Guidelines for Procedures in the Assessment of Elements of Abuse of Authority (Official Gazette Number 1267 of 2015), Article 2 paragraph (2).

${ }^{10}$ Mukti Fajar ND dan Yulianto Achmad, Dualisme Penelitian Hukum Normatif dan Empiris, (Yogjakarta: Pustaka Pelajar, 2010), pg. 93.

14 Ari Wibowo, "PENENTUAN KRITERIA UNSUR PENYALAHGUNAAN WEWENANG DALAM PERKARA TINDAK PIDANA KORUPSI (STUDI PUTUSAN PENGADILAN),” Yuridis 7, no. 1 (2020): 12048, https://core.ac.uk/download/pdf/327205589.pdf.

15 Yedi Purwanto and Ridwan Fauzy, "ANALISIS TERHADAP HUKUM ISLAM DAN HUKUM POSITIF DALAM PEMBERANTASAN KORUPSI DI INDONESIA” $15, \quad$ no. 2 (2017): 127-40, http://jurnal.upi.edu/file/05_Analisis_Terhadap_Hukum_Islam_-_Yedi_P1.pdf.

${ }^{16}$ Setiadi Wicipto, "Korupsi Di Indonesia Penyebab, Hambatan, Solusi Dan Regulasi," Legislasi Indonesia 15, no. 3 (2018), https://e-jurnal.peraturan.go.id/index.php/jli/article/view/234. 
nepotism, causes state finances to paralyze, destabilizes the trust of donor countries and foreign investors, fosters various types of crime in society, and causes demoralization among the community. Corruption by the Government can be prevented through clean government administration (bureaucracy) and away from harmful practices. This can be done through the active involvement of state administrative law, through guarding and providing legal certainty for actions so as not to violate the rules and guarantees of human rights, and must be able to distinguish between the interests of the state "state administration" which is imposed on the needs and accountability of every citizen. ${ }^{17}$ Soerjono Soekanto also conveyed that the ruler in the sense of the government is the determinant of the fate of millions of people. So that the good and bad judgment lies in how much benefit is provided to the people. ${ }^{18}$ Then it is time for the government to love the people as much as they love their families. So that the government took all steps in the development, economic, social, and political processes to achieve one goal, namely a just and prosperous society, the relationship between corruption and the government can be seen from 3 stages, as stated by Syed Hussein Alatas. ${ }^{19}$ As follows: (1) The stage in which corruption is relatively restricted without affecting a wide range of social life. In this condition, the government carries out its mandate as a public servant very well, based on standard operating procedures. At this stage, corruption is genuinely a prohibited act; (2) The second stage is where corruption becomes rampant and all-pervading. This condition illustrates that almost all governments, both at the central and regional levels, are corrupt. There are almost no clean public services without facilitation payments to get their rights as a society; (3) The third stage of corruption is the most interesting, at all-time most challenging to notice. At this stage, corruption has damaged every aspect of life, including ethics and morals. It is tough to trust various institutions within the state, because almost all essential elements, including the executive, judiciary, and legislature, are infected with this corruption virus.

It needs to be emphasized here that the criminal act of corruption is not only an act that results in state losses but an act of maladministration in which a state administrator in his position abuses his authority by giving or promising something, doing or not doing something in his position that is contrary to his obligations. In the author's opinion, this picture indicates the abuse of authority committed by state officials, so they should be subject to criminal sanctions. ${ }^{20}$ When viewed from an administrative law perspective, corruption cannot be viewed through a criminal law approach alone because this perspective is too narrow. This a quo approach only makes criminal law the primary and only means of hitting, just fighting it without preventive action. Corruption commonly carried out by government officials is closely related to state administrative law. In carrying out their duties, government officials are subject to the norms and rules of administrative law. Philippus M. Haddon Said, "the role of administrative law cannot be ignored in relation to criminal acts of corruption, both in terms of prevention and repressive". ${ }^{21}$

Corrupt actions by the government related to the categorization of maladministration by the government can be prevented through supervision. This concept is included in the Perma

\footnotetext{
${ }^{17}$ Sjahran Basah, Eksistensi dan Tolak Ukur Badan Peradilan Administrasi di Indoneisa, (Bandung : Alumni, 2014), pg. 3.

${ }^{18}$ Jawade Hafidz Arsyad, Korupsi dalam Perspektif HAN (Hukum Administrasi Negara), (Jakarta: Sinar Grafika, 2015), pg. 71.

${ }^{19}$ Syed Hussein Alatas in Haryono Umar, Corruption the Devil (Jakarta: Universitas Trisakti, 2017). 105-112.

20 Odie Faiz Guslan, "TINJAUAN YURIDIS MENGENAI BATASAN ANTARA PERBUATAN MALADMINISTRASI DENGAN TINDAK PIDANA KORUPSI,” JCH (Jurnal Cendekia Hukum) 4, no. 1 (September 28, 2018): 9, https://doi.org/10.33760/jch.v4i1.38.

${ }^{21}$ Abdul Muttalib, "EFEKTIVITAS PENEGAKAN HUKUM TERHADAP PENYIDKAN TINDAK PIDANA KORUPSI OLEH KEPOLISIAN DAERAH SULAWESI SELATAN," Al Hikam 1, no. 1 (2017), https://media.neliti.com/media/publications/287963-efektivitas-penegakan-hukum-terhadap-pen-0d0052ba.pdf.
} 
Abuse of Authority, namely the concept of internal control. The surveillance model introduced by Gorge R. Terry includes ${ }^{22}$ :

a. Optimization of results which is a common goal to avoid acts of abuse of authority;

b. Effectiveness and efficiency in the use of funds, energy, materials, and time to be made efficient;

c. Accountability for each implementation of assessment work can be done through reports (oral and written, and direct inspection;

d. Comparison between the supervision that has been carried out with the results in the field, and correcting it so that it becomes material for evaluation;

e. Follow-up action evaluation results to repair parts that must be repaired immediately or which are not yet necessary to be repaired from the results of the supervision;

The development of the trajectory of state administrative law in cases of criminal acts of corruption lies in the element of abuse of authority carried out by state administrators, both in the domain of government or business entities, which results in state losses. Material offenses in abuse of authority have elements detrimental to state finances and illegal acts by the government that give the impression of criminalization of policies. The discourse of abuse of authority and abuse of authority is bound by two areas of legal study, namely administrative law and criminal law. The concept of abuse of authority is a concept known in the study of state administrative law. However, this concept was adopted by criminal law studies that have developed independently in their journey, although not completely independent. The intersection of the concept of abuse of authority between state administrative law and criminal law lies at the link point of the administration of the government itself. Every governmental norm based on state administrative law is followed by criminal provisions or known as in cauda venenum, which means "there is poison in the tail". Because in fact, criminal law can be said to be an all-embracing act and an all Purposing act that functions as a spider's web that ensnares every criminal act. However, this concept only applies to offenders who come from the community. At the same time, state administrators can be subject to direct criminal penalties if they can be proven to have committed acts of corruption through misuse of authority.

2. Reviewing the elements of abuse of power against government decisions

The law enforcement paradigm in the PTUN underwent a very significant change after the issuance of the AP Law. Currently, the PTUN is given the authority "to receive, examine and decide upon applications related to whether or not there is an abuse of authority in an act or decision". Before the issuance of the GA Law, the object of dispute in the PTUN was "disputes arising in the field of State Administration between a person or civil legal entity and State Administrative Bodies or Officials, both at central and regional levels, as a result of the issuance of a State Administrative Decree including employment disputes based on the prevailing laws and regulations". ${ }^{23}$

The authority of the PTUN is obtained by attribution through the GA Law itself and through the Supreme Court Regulation on Abuse of Authority. The authority of PTUN can be seen explicitly in Article 21 paragraph (1) of the GA Law "The court has the authority to accept, examine, and decide whether or not there is an element of abuse of authority committed by Government Officials". Dan dalam Pasal 2 ayat (1) Perma Penyalahgunaan Wewenang "Pengadilan berwenang menerima, memeriksa, dan memutus permohonan penilaian ada atau tidak ada penyalahgunaan Wewenang dalan Keputusan dan/atau

23 Law Number 5 Year 1986 regarding State Administrative Courts (State Gazette of the Republic of Indonesia Year 1986 Number 77), Article 1 point 4 
Tindakan Pejabat Pemerintahan sebelum adanya proses pemidanaan". (garis bawah oleh penulis). Implikasi putusan dari PTUN terhadap unsur penyalahgunaan wewenang jika terbukti bersalah dan ada niat jahat maka dapat dilanjutkan ke peradilan pidana jika putusan menyatakan tidak bersalah maka tidak dapat dilanjutkan prosesnya. Hal ini dikarenakan tidak terpenuhinya bestand delict sebagaimana yang tertuang dalam Pasal 3 UU TIPIKOR. ${ }^{24}$ Konsep menyalahgunakan kewenangan di dalam Pasal 3 UU TIPIKOR adalah "(s)etiap orang yang dengan tujuan menguntungkan diri sendiri atau orang lain atau suatu korporasi, menyalahgunkan kewenangan, kesempatan atau sarana yang ada padanya karena jabatan atau kedudukan yang dapat merugikan keuangan negara atau perekonomian negara,...." (garis bawah oleh penulis).

There are prerequisites for illegal acts in its development related to the elements in Article 3 of the Corruption Law. Then on the phrase abusing authority, there is an interpretation conveyed by Indriyanto Seno Adji into three forms:

\section{Abuse of authority to perform actions that are contrary to the public interest} or benefit individuals, groups, or groups

2. Abuse of authority in the sense that the official's action is intended adequately for the public interest but deviates from the purpose of granting said authority by law or other regulations;

3. Abuse of authority in the sense of abusing procedures that should be used to achieve specific goals, but have used other procedures to make it happen.

Furthermore, the matter of "detrimental to state finances" is an objective factor of the conceptual act of abusing this authority. Because it is stated that a decision or policy is an act of abuse of authority if it can be proven that the decision or policy causes a loss to state finances preceded by evidence of an illegal act. ${ }^{25}$ The big question is whether pure abuse of authority is a discussion in state administrative law so that only administrative punishment is needed. It does not require criminal law. Given the elements in Article 3 of the Corruption Law, state losses are only objective elements. The excesses arising from the expansion of the PTUN's competence led to an interesting discourse, especially on the sanctions imposed by state administrative law and criminal law on government officials who were proven to have made mistakes. According to Jensen, the relationship between state administration and criminal law is divided into two. First, low degree differentiation imposes administrative sanctions that do not rule out criminal sanctions due to different characteristics and objectives. Second, high degree differentiation is the existence of administrative sanctions that must be separated from criminal sanctions. ${ }^{26}$ Departing from the above discourse, the abuse of power can only be done by those who have authority and positions based on attribution, delegation, and mandate. Attribution is the authority that is in the agency or official delegated based on statutory regulations. ${ }^{27}$ Meanwhile, delegation is defined as the matter of transferring an authorized body or not. So that if the authority is less than perfect, it means that decisions based on authority are not valid according to law. ${ }^{28}$ The mandate itself has no recognition of authority or transfer of authority because the mandate is still the authorized and responsible person.

\footnotetext{
${ }^{24}$ Aju Putrijanti, Kompetensi PERATUN ..., pg. 109.

${ }^{25}$ Nehru Asyikin, "Pengawasan Publik Terhadap Pejabat Publik Yang Melakukan Tindakan Korupsi: Perspektif Hukum Administrasi," Jurnal Wawasan Yuridika 4, no. 1 (March 31, 2020): 80, https://doi.org/10.25072/jwy.v4i1.316.

${ }^{26}$ Philippus M Hadjon, et.al., Pengantar Hukum Administrasi Indonesia cetakan kesembilanbelas, (Yogjakarta: Grafika, 2019), pg. 125-126.

${ }^{27}$ Philippus M Hadjon, et.al., Pengantar Hukum Administrasi Indonesia cetakan kesembilanbelas, (Yogjakarta: Grafika, 2019), pg. 125-126.

${ }^{28}$ Ibid.
} 
If referring to the opinion above, then the person who can take action to make a decision or policy is someone who has the authority that can be based on attribution and delegation, while the mandate can only act according to what has been regulated in writing what scope can be implemented. Criminal law only recognizes that someone who holds a position through a mandate cannot be held accountable and subject to criminal sanctions because the mandate only carries out what is ordered by the superior. The most significant effect of abuse of power lies in the relationship between opportunities for corruption with the rank of office or power held, and the economic level is closely linked. People who have the power open up opportunities or encourage corruption, and only people in high positions can do this because they can make and make policies and decisions. People who have a good economy have the opportunity to pay through bribes (bribery).

Usually, officials will be "addicted" to stay in power, and many of them do not want to give up the power they already hold ${ }^{29}$ Also, people who are not yet in power will try their best to occupy a position through bribery. A phenomenon like this will give rise to a happy attitude (ABS) and a hypocrite attitude. Regarding the abuse of power, the regulatory procedure has been detailed in the Perma on abuse of authority, namely the request for a test whether or not there is an element of abuse of authority can only be filed if it was before the criminal process and after the results of supervision from the government internal control apparatus. The GA Law itself in attribution gives authority to the Government Internal Control Apparatus or Aparat Pengawasan Intern Pemerintah (APIP) under Article 20 paragraph (1) that the supervision of the prohibition of abuse of power is carried out by APIP with the results of the supervision contained in Article 20 paragraph (2) of the GA Law, consisting: $a$. there is no error; $b$. there is an administrative error; $c$. there is an administrative error that causes loss to state finances.

Referring to the phrase contained in the Perma Abuse of Authority, it can be concluded that the PTUN does not immediately resolve the polemic of the authority to judge. ${ }^{30}$ The PTUN decision is only an entry point; if it turns out that the supervision results by APIP are requested to the PTUN and are decided clearly and stating "there was an administrative error that caused losses to state finances," then it can proceed to criminal proceedings. An explanation of who the APIP is and its roles and responsibilities are regulated in Government Regulation No. 60 of 2008 concerning the Government Internal Control System, which states that the APIP consists of: a). BPKP; b). Inspectorate General or other names which functionally carry out internal control; c). Provincial Inspectorate; and d). District/City Inspectorate (Article 49 paragraph 1). ${ }^{31}$ This is because this Government Regulation came out earlier than the GA Law. The function of APIP is very strategic in dealing with abuse of power by government officials. APIP can act in preventing and overcoming criminal acts of corruption by collaborating with other law enforcers. ${ }^{32}$ Because APIP can report directly to Government Officials, it inspects the Corruption Court; this method makes it easier to tackle corruption. Apart from that, the results of the APIP examination are also used as evidence that does not need to be tested by the panel of judges in the State Administrative Court when examining the elements of ongoing abuse of authority. Therefore, the APIP institution must be independent and work objectively and professionally.

\section{Case Analysis in Reviewing the Elements of Abuse of Power}

\footnotetext{
${ }^{29}$ Jawade Hafidz dalam Korupsi dalam perspektif HAN.... pg. 98.

${ }^{30}$ Aju Putrijanti, Kompetensi Peratun untuk memeriksa Unsur .....pg. 116.

${ }^{31}$ Muhammad Yasin. et.al., Anotasi UU Nomor 30 Tahun 2014 ......pg. 106

${ }^{32}$ Marojahan Panjaitan, "PENYELESAIAN PENYALAHGUNAAN WEWENANG YANG MENIMBULKAN KERUGIAN NEGARA MENURUT HUKUM ADMINISTRASI PEMERINTAHAN," Jurnal Hukum IUS QUIA IUSTUM 24, no. 3 (July 2017): 431-47, https://doi.org/10.20885/iustum.vol24.iss3.art5.
} 
The examination of the application for whether or not there is an element of abuse of authority will be challenged with cases that have entered the PTUN among them: with "the application is there or does not have an element of abuse of authority" with a number: 250/P/PW/2015/PTUN-JKT, then the application is continued with a test of authority Number: 257/P/PW/2015/PTUN-JKT which is appealed to PTTUN DKI Jakarta Number: 110/B/2016/PT.TUN.JKT. The next case that will be the object of this research is Andrey Dulu, Acting Regional Secretary of East Borito Regency with Number: 15/P/PW/2016/PTUN.PLK. Referring to the provisions of the Perma, the abuse of authority that can be used as the object of application is a government decision/action that has not yet been sentenced and after the results of supervision from APIP. For this reason, it is necessary to see how the disputed object is in the existing decisions.

First, in the case with Case Number: 250/P/PW/2015/PTUN-JKT, the applicant was Drs. H. Surya Dharma Ali, M.Si. Former Minister of Religion for the 2009-2014 period in his application which became the object of the application, namely: The object of this petition is to determine whether or not there is an abuse of authority in the petitioner's actions and/or administrative policies relating to the following: ${ }^{33}$

(1) Use of Ministerial Operational Fund or Dana Operasional Menteri (DOM) of the Ministry of Religion of the Republic of Indonesia in 2011-2014; and;

(2) Implementation of Hajj in 2010-2013, particularly regarding the appointment of PPIH, the appointment of Amirul Hajj's accompanying officers, rental of lodgings in Saudi Arabia, and the utilization of the remaining national quota.

From the object of the petition, the applicant describes the reasons for the petition stating that the applicant committed no administrative violation regarding the use of DOM. The petitioner thinks that the applicant has the authority to manage and use DOM as regulated in Article 6 paragraph (1) and paragraph (2) letter b of Law Number 13 of 2003 concerning State Finances. However, the results of the report from the BPKP are based on the Ministerial Operational Fund Expenditure Cash Book for the 2009-2014 fiscal year. The applicant is deemed to have committed an act of abuse of authority, namely by using his position using visa processing fees, airport tax fees at the airport, accommodation costs for work visits of the Minister of Religion, documentation fees at the State Palace, payment of official travel tickets/jobs, and assistance/donations to certain parties other activities. ${ }^{34}$ The reason for the object of the second application is "Hajj Implementation Policy". Following the attribution authority granted by law, the applicant has the right to formulate, make, stipulate and implement policies in the religious field, including policies in the implementation of the haj pilgrimage. However, in the results of the BPKP report, the applicant is deemed to have committed an abuse of authority for the following reasons: ${ }^{35}$

(a) Appointing persons who do not meet the requirements to become Officials of the Saudi Arabian Hajj Organizing Committee or Petugas Panitia Penyelenggara Ibadah Haji (PPIH);

(b) Appointing a companion officer for Amirul Hajj is not by the provisions;

(c) Directing the Indonesian Hajj Pilgrims' Housing Rental Team in Saudi

Arabia to appoint a housing provider for Indonesian Hajj pilgrims in Saudi

Arabia is not following the provisions; and

\footnotetext{
${ }^{33}$ State Administrative Court Decision Number 250/P/PW/2015/PTUN-JKT regarding the case decision Drs. H. Surya Dharma Ali, 18 January 2016, pg. 3.

${ }^{34}$ State Administrative Court Decision Number 250/P/PW/2015/PTUN-JKT regarding the case decision Drs. H. Surya Dharma Ali, 18 January 2016, pg. 9.

${ }^{35}$ State Administrative Court Decision Number 250/P/PW/2015/PTUN-JKT regarding the case decision Drs. H. Surya Dharma Ali, 18 January 2016, pg. 13.
} 
(d) Using the remaining quota for national pilgrimage is not based on the principles of justice and proportionality.

The consideration of the panel of judges with the verdict "Declaring the Petitioner's Petition cannot be accepted" was because, at the time of examining the quo case, the Corruption Crime Court was in progress. The judge's opinion is per the Perma Abuse of Authority provisions; namely, the petition for the element of abuse of authority can be accepted if the examination has been completed by APIP and has not entered the criminal legal process.

Furthermore, the second case is still with the same applicant with case number: 257/P/PW/2015/PTUN-JKT, namely petitioning the object of the petition: ${ }^{36}$

(1) Investigation Warrants or Surat Perintah Penyidikan (SPRINDIK) issued

by the Corruption Eradication Commission or Komisi Pemberantasan Korupsi (hereinafter referred to as KPK) include:

a. SPRINDIK No: Sprin.Dik-27/01/05/2014, 22 May 2014;

b. $\quad$ SPRINDIK No: Sprin.Dik-27A/01/12/2014, 24 December 2014 ;

c. SPRINDIK No: Sprin.Dik-/3/01/06/2015, 1 June 2015 ;

d. SPRINDIK No: Sprin.Dik-086/01/02/2015, 13 February 2015 ;

(2) Letter issued by the Financial and Development Supervisory Agency or Badan Pengawasan Keuangan dan Pembangunan (hereinafter referred as BPKP) No: SR-549/D6/I/201, 5 August 2015 dan Surat BPKP No:550/D6/I/2015, August 2015 regarding the Report on the Calculation of State Financial Losses

(3) There was an act of abuse of the KPK's authority in determining the petitioner as a suspect

(4) The existence of acts of abuse of BPKP's authority in calculating and determining the existence of state losses is groundless and authorized to determine the loss;

(5) There were actions by the KPK in issuing the Indictment No: DAK28/24/082015, 21 August 2015, is invalid and has no binding legal force and exceeds the authority; therefore, the quo indictment is null and void by law

The basic description of the petition is that there was an Act of Abuse of Authority by the KPK and BPKP, which resulted in the petitioner's interest being harmed because it was not based on the results of the state's financial loss report. In addition, the KPK has just issued a State Financial Loss Report contradicting the signs limiting the scope of its authority, which is classified as going beyond the authority that does not uphold independence and objectivity as a requirement and obligation of the KPK in exercising its authority based on Article 56 of Government Regulation Number 60 of 2008 concerning Government Internal Control System, so that it only serves as a means of justifying BAP's statement by the KPK, which the KPK is not authorized as an institution that can determine the existence of state financial losses except the BPK Agency itself. Also, based on article 3, letter f of Presidential Decree No. 192 of 2014 concerning BPKP requires the KPK to carry out their duties. Authorities must carry out the function of coordinating and synergizing the organizers of the internal control together with other government internal supervisory apparatus so that the actions taken by the KPK and BPKP constitute an act of abuse of authority that seems to have declared someone a target for investigation so that the direction and target of the investigation process are known in the Object of the Request for Authority Testing.

The judge's consideration by deciding the quo case "Declaring the Petitioner's Petition cannot be accepted" was because, following the intention of giving PTUN authority as referred to in Article 21 of the Government Administration Law, the State Administrative

${ }^{36}$ State Administrative Court Decision Number 250/P/PW/2015/PTUN-JKT regarding the case decision Drs. H. Surya Dharma Ali, 21 January 2016, pg. 3-4. 
Court in absolute terms is not authorized to adjudicate the applicant's petition. The Petitioners' legal standing and the main points of the petition do not need to be reconsidered. An appeal to PT followed this decision.TUN DKI Jakarta with case number: 110/B/2016 /PT.TUN.JKT. The decision of the Panel of Judges, namely strengthening the decision of the DKI Jakarta State Administrative Court.

Referring to the course of the case that ensnared Surya Dharma Ali, it can be seen from the time description as follows: On 7 December 2015, Surya Dharma Ali submitted an application and was decided on 21 January 2016. Then on 24 November 2015, Surya Dharma Ali applied and was decided on 18 January 2016. As well as for the application dated 7 December 2015, there was an appeal to PTTUN on 26 January 2016, with the same decision, namely that the application could not be accepted. At the same time, Surya Dharma Ali has also undergone a criminal process with the commencement of detention on 10 April 2015. The decision of the Central Jakarta District Court on 23 December 2015 stated that it was "legally and convincingly proven guilty of committing a criminal act of corruption as regulated and punishable by punishment in Article 3 of the Corruption Law". ${ }^{37}$ Subsequently, an appeal was made to the High Court of the Special Region of Indonesia (DKI) with the verdict "... sentenced the defendant to 10 (ten) years imprisonment....". ${ }^{38}$. Then another legal reconsideration attempt was made to the Supreme Court by petitioner Surya Dharma Ali with the verdict "rejecting the request for reconsideration from Petitioner Reconsideration/Convicted, Suryadharma Ali ...". 39

From the description of the Suryadharma Ali case, the opinion of the judge rejected the request for testing the element of abuse of power was correct considering the criminal process had started. Then the application for testing the element of abuse of authority was submitted to the PTUN. The following case is case number 15/P/PW/2016/PTUN.PLK. The petitioner in this a quo case is Andrey Dulu, a retired Civil Servant in Kab. Barito, Central Kalimantan Province. The object of the petition for the quo case is the Order of the Head of the Tamiang District Prosecutor's Office No. PRINT-01 /Q.2.16/Fd.1/07/2014 dated 1 July 2014, which implicitly states that the applicant has abused his authority in deviation from the implementation of Land Compensation for the hero grave garden in Jawetan Village, Kec. East Hamlet, Kab. East Barito 2012 fiscal year. ${ }^{40}$ The petitioner petitions that the petitioner is the Acting Officer (Plt) of the Regional Secretary of the District. East Barito based on East Barito Regent Instruction Number 06 Yahun 2012 dated 27 July 2012 starting from 1 August 2012, the Ex Officio also serves as the committee chairman (Team Nine). Land acquisition for the hero grave garden is not an act of abuse of authority. The panel of judges tried the quo case by "Declaring the Petitioners' Petition to be unacceptable" with legal considerations that the Petitioners were currently undergoing examination at the trial for criminal acts of corruption.

Suppose we refer to the journey of the case that caught Andrey in the past. In that case, it can be seen from the time description as follows: On 14 April 2016, Andrey Dulu filed a petition and was decided on 16 May 2016 with a decision "stating that the Petitioner's Petition cannot be accepted".

At the same time, Andrey Dulu has also undergone a criminal process with the commencement of his detention on 22 July 2016. The decision of the Palangka Raya District

\footnotetext{
37 The Central Jakarta District Court Number 93/Pid.Sus/TPK/2015/PN.Jkt.Pst regarding the Surya Dharma Ali case decision dated 23 December 2015,pg. 3.

38 The High Court of the Special Region of Jakarta Number 25/ PID/TPK/2016/PT.DKI regarding the decision of the Surya Dharma Ali case dated 12 May 2016,pg. 504.

${ }^{39}$ Supreme Court Decision ......pg. 17.

${ }^{40}$ The decision of the State Administrative Court Number 15/P/PW/2016/PTUN.PLK regarding the verdict in the case of Andrey Past, 19 May 2016, pg. 3.
} 
Court on 30 November 2016 stated that "it is legally and convincingly proven guilty of committing a criminal act of corruption as the primary indictment ...". ${ }^{41}$ Subsequently, an appeal was made to the Palangka Raya High Court with the verdict ".... amending the previous decision by paying replacement money ....". ${ }^{42}$ Then another appeal was made to the Supreme Court (MA) by the Petitioner Andrey Previously with the decision "rejecting the appeal for cassation from Cassation Petitioner II/Defendant ....". ${ }^{43}$ There is something that attracts attention from these two decisions, namely the distortion of the judge's consideration in examining and deciding cases, namely in the case decision 257/P/PW/2015/PTUN-JKT 15/P/PW/2016 / PTUN.PLK. In 257/P/PW/2015/PTUN-JKT states that the Investigation Warrant is not the object of a request for abuse of authority as referred to in Article 21 of the GA Law decision case number 15/P/PW/2016/PTUN.PLK, the judge does not state the reasons for these considerations. Referring to Article 18 paragraph (1) of the GA Law, which reads, the categorization of abuse of authority is: a. has exceeded the term of office or the time limit of the validity of the authority; $b$. exceeding the territorial limits of the validity of authority; and/or c. contrary to the provisions of laws and regulations. Whereas in the Perma Abuse of authority that PTUN can accept, examine and decide on the testing of elements of abuse of authority for two reasons, namely before the criminal process and after the issuance of the APIP supervision report. The author agrees with the judge who gave reasons for legal considerations in case number 257/P/PW/2015/PTUN-JKT because it is not included in the categorization that becomes the object of testing abuse of power as contained in the Perma abuse of power. Because the Investigation Warrant is not part of the APIP as previously explained. So it is true what was conveyed by Enrico Parulian Simanjuntak. "testing of abuse of power in this aspect is very limited when compared to the broad scope and complexity of the definition of abuse of power in administrative law". 44

\section{Paradigmatic Concept of Authority Abuse Testing}

Abuse of power is a concept known in the realm of discussion of state administrative law, which is transformed into an act of abusing authority in the realm of criminal law. ${ }^{45}$ State administrative law through the concept of abuse of power is a preventive measure for preventing corruption. Through the concept of abusing authority, criminal law becomes a repressive legal remedy for law enforcement on corruption. Abuse of power and abuse of authority have their respective legal domains that are closely related. The GA Law guarantees legal certainty for state administrators in taking actions or decisions to run the wheels of government following general principles of good governance. Even so, the Corruption Law provides guarantees to the state against the actions of government officials that harm state finances and obstruct the wheels of government and development.

Between state administrative law and criminal law, there is a point of contact with gray areas, including dialectics in case handling. However, there are differences between them,

\footnotetext{
${ }^{41}$ Palangka Raya District Court Decision Number 40/Pid.Sus-TPK/2016/PN.Plk. Regarding the verdict of Andrey's case in the past, 23 February 2017, pg. 132

${ }^{42}$ Palangka Raya High Court Decision Number 1/Pid.Sus-TPK/2016/PT.Plk. Regarding the verdict of Andrey's case in the past, 30 November 2016, pg. 39

${ }^{43}$ Supreme Court Decision Number 1055/K/Pid.Sus/2017, regarding the verdict of Andrey's case in the past, 26 July 2017, pg. 99

${ }^{44}$ Enrico Parulian Simanjuntak, "PENGUJIAN ADA TIDAKNYA PENYALAHGUNAAN WEWENANG MENURUT UNDANG-UNDANG ADMINISTRASI PEMERINTAHAN / EXAMINATION TO DETERMINE THE PRESENCE OR ABSENCE OF ABUSE OF AUTHORITY ACCORDING TO GOVERNMENT ADMINISTRATION LAW," Jurnal Hukum Dan Peradilan 7, no. 2 (July 29, 2018): 237, https://doi.org/10.25216/jhp.7.2.2018.237-262.

${ }^{45}$ http://justitialawfirm.or.id/2017/04/29/menyalahgunakan-kewenangan-dalam-tindak-pidana-korupsi-danpenyalahgunaan-wewenang-pada-hukum-administrasi/ Justicia Law Firm, diakses tanggal 28 Januari 2021.
} 
namely: ${ }^{46}$ (1) State administrative law is administrative in nature while criminal law is repressive in nature; (2) State administrative law focuses on excellent and correct government administration based on: (1) legality principles; (2) principles of protection of human rights; (3) general principles of good governance, while criminal law emphasizes a system of repression (repressive); (3) One of the objectives of state administrative law is to create legal certainty and prevent abuse of authority, while criminal law has the main objective of recovering or saving state financial losses.

The harmony between the two must go on with the intention of change and improvement. There are legal consequences to the application of this concept in the trajectory of state administrative law and criminal law. If the GA Law is applied in a legal event and it turns out that the final decision of the Panel of Judges decides there is no element of abuse of power by government officials, law enforcement officials cannot enter into the process of investigation and investigation of Corruption Crime regulated in the Corruptions Law. The formation of the GA Law aspires to regulate governance in various sectors. The urgency was conveyed by the Minister of PAN-RB Taufiiq Effendi in Surabaya, 18 September 2007:47

The presence of this Law, on the one hand, will become the legal basis for government agencies in determining decisions and legal actions in the process of government administration. On the other hand, it also requires fundamental changes, patterns of thought, and cultural patterns of government administration, from previously tending to abuse authority and acting arbitrarily to become law-abiding officials and placing citizens as legal subjects.

In addition, it is hoped that the GA Law will provide more answers to every nation's problems, especially on corruption. Besides being a technical guideline in making policies and regulations by state administrators, the GA Law also has regulatory norms related to material law in the object of disputes in PTUN. Corruption action is indeed necessary to build justice and provide a deterrent effect so that other potential actors think twice about doing the same thing. But not all corruption problems are resolved by the prosecution. ${ }^{48}$ Prevention is needed through the principles of good governance, one of which is not taking arbitrary actions. In the two cases used as the object of research, it appears that the instrument of testing has or does not have an element of abuse of authority only to hide oneself from being ensnared from the criminal act of corruption. Because the two cases mentioned above have committed a criminal act of corruption with a verdict that has been incremental and has permanent legal force.

In connection with the corruption problems that have been rife lately, it is necessary to prepare a corruption eradication system that includes the following: ${ }^{49}(1)$ Government organizations must be able to prevent, prevent and easily detect incidents of corruption through a series of efforts to prevent (preventive) corruption; (2) Each government agency must also prepare a system to be able to detect, reveal facts of incidents, and follow up following applicable regulations or more commonly referred to as investigative and repressive actions; (3) Every government organization should continuously carry out education (education) and increase understanding related to the development of an anticorruption spirit (an area free from the slightest corruption).

\section{Conclusion}

\footnotetext{
${ }^{46}$ Disiplin F Manao, "Penyelesaian Penyalahgunaan Wewenang Oleh Aparatur Pemerintah Dari Segi Hukum Administrasi Dihubungkan Dengan Tindak Pidana Korupsi," Jurnal Wawasan Yuridika, vol. 2, March 31, 2018, http://www.sthb.ac.id/ejournal/index.php/jwy/article/view/158.

${ }^{47}$ Muahammad Yasin, et.al. Anotasi UU Nomor 30 Tahun 2014.... pg. 5.

${ }^{48}$ Haryono Umar, Corruption the Devil...pg. 469.

${ }^{49}$ Haryono Umar, Corruption the Devil...pg. 475.
} 
The implementation of the concept of testing the elements of abuse of power in the GA Law has experienced refraction or distortion in its application. Testing the abuse of power essentially aims to balance so that there is no criminalization in policymaking by the government. However, in practice, based on the research that has been discussed, instruments of abuse of authority are used as an effort to save oneself from being caught in criminal acts of corruption. This is refraction from the initial ideals of the formation of the GA Law. The GA Law was formed so that officials are not accused of abuse of authority, and the Law is also a reference for not taking arbitrary actions by state officials. It is seen from the discussion of the two cases that have been reviewed, where it can be seen that Suryadharma Ali and Andrey Dulu tried their $\mathrm{r}$ luck by submitting a request for testing the elements of abuse of power to the PTUN while the criminal process was ongoing. This action illustrates the use of the concept of abuse of power in the PTUN because if the PTUN decision says there is no element of abuse of power, the district court will not process criminal law.

\section{Bibliography}

\section{A. Book}

Arsyad, Jawade Hafidz. Korupsi dalam Perspektif HAN (Hukum Administrasi Negara). Jakarta: Sinar Grafika. 2015

Basah, Sjahran. Eksistensi dan Tolak Ukur Badan Peradilan Administrasi di Indoneisa. Bandung: Alumni. 2014.

Dillon, HS. Melawan Korupsi Dari Aceh sampai Papua (10 Kisah Pemberantasan Korupsidi Indonesia). Jakarta: PT. Penebar Swadaya. 2006.

Hadjon, Philippus M. Pengantar Hukum Administrasi Indonesia cetakan kesembilanbelas. Yogjakarta: Grafika. 2019.

Latif, Abdul. Hukum Administrasi dalam Praktik Tindak Pidana Korupsi. Jakarta: Prenada Media Grup. 2014.

ND, Mukti Fajar. Dualisme Penelitian Hukum Normatif dan Empiris. Yogjakarta: Pustaka Pelajar. 2010.

Umar, Haryono. Corruption the Devil. Jakarta: Universitas Trisakti. 2017.

Yasin, Muhammad, and et.al. Anotasi UU Nomor 30 Tahun 2014 Tentang Administrasi Pemerintahan. Jakarta: Center for Study of Governance and Administrative Reform. 2017.

\section{B. Journal}

Ansori, Lutfil. "DISKRESI DAN PERTANGGUNGJAWABAN PEMERINTAH DALAM PENYELENGGARAAN PEMERINTAHAN.” Jurnal Yuridis. Vol. 2, August 25, 2015. https://doi.org/10.35586/.V2I1.165.

Asyikin, Nehru. "Pengawasan Publik Terhadap Pejabat Publik Yang Melakukan Tindakan Korupsi: Perspektif Hukum Administrasi." Jurnal Wawasan Yuridika 4, no. 1 (March 31, 2020): 80. https://doi.org/10.25072/jwy.v4i1.316.

Fransiska Adelina Sinaga. "BENTUK-BENTUK KORUPSI POLITIK .” Legislasi Indonesia 16, no. 01 (2019). https://e-jurnal.peraturan.go.id/index.php/jli/article/view/256.

Guslan, Odie Faiz. "TINJAUAN YURIDIS MENGENAI BATASAN ANTARA PERBUATAN MALADMINISTRASI DENGAN TINDAK PIDANA KORUPSI.” JCH (Jurnal Cendekia Hukum) 4, no. 1 (September 28, 2018): 9. https://doi.org/10.33760/jch.v4i1.38.

Kumalaningdyah, Nur. "Pertentangan Antara Diskresi Kebijakan Dengan Penyalahgunaan Wewenang Dalam Tindak Pidana Korupsi." Jurnal Hukum Ius Quia Iustum 26, no. 3 (September 1, 2019): 481. https://doi.org/10.20885/iustum.vol26.iss3.art3. 
Manao, Disiplin F. "Penyelesaian Penyalahgunaan Wewenang Oleh Aparatur Pemerintah Dari Segi Hukum Administrasi Dihubungkan Dengan Tindak Pidana Korupsi." Jurnal Wawasan Yuridika. Vol. 2, March 2018. http://www.sthb.ac.id/ejournal/index.php/jwy/article/view/158.

Muttalib, Abdul. "EFEKTIVITAS PENEGAKAN HUKUM TERHADAP PENYIDKAN TINDAK PIDANA KORUPSI OLEH KEPOLISIAN DAERAH SULAWESI SELATAN." $\quad A l$ Hikam $1, \quad$ no. 1 (2017). https://media.neliti.com/media/publications/287963-efektivitas-penegakan-hukumterhadap-pen-0d0052ba.pdf.

Panjaitan, Marojahan. "PENYELESAIAN PENYALAHGUNAAN WEWENANG YANG MENIMBULKAN KERUGIAN NEGARA MENURUT HUKUM ADMINISTRASI PEMERINTAHAN." Jurnal Hukum IUS QUIA IUSTUM 24, no. 3 (July 2017): 431-47. https://doi.org/10.20885/iustum.vol24.iss3.art5.

Putrijanti, Aju, and Lapon Tukan Leonard. "Kompetensi Peratun Untuk Memeriksa Unsur Penyalahgunaan Wewenang." Jurnal IUS Kajian Hukum Dan Keadilan 7, no. 1 (April 23, 2019): 107-27. https://doi.org/10.29303/ius.v7i1.605.

Sahlan, Muhammad. "Unsur Menyalahgunakan Kewenangan Dalam Tindak Pidana Korupsi Sebagai Kompetensi Absolut Peradilan Administrasi." Jurnal Hukum IUS QUIA $\begin{array}{llllll}\text { IUSTUM 23, } & \text { no. } 2016 \text { ): }\end{array}$ https://doi.org/10.20885/iustum.vol23.iss2.art6.

Satriya Nugraha. "KONSEP PENYALAHGUNAAN WEWENANG DALAM UNDANGUNDANG TINDAK PIDANA KORUPSI DI INDONESIA." Sociosciientia 8, no. 1 (March 2016): 15-22. https://lldikti11.ristekdikti.go.id/jurnal/pdf/d3246e7b-3092-11e89030-54271eb90d3b/.

Setiadi Wicipto. "Korupsi Di Indonesia Penyebab, Hambatan, Solusi Dan Regulasi." Legislasi Indonesia 15, no. 3 (2018). https://e-jurnal.peraturan.go.id/index.php/jli/article/view/234.

Simanjuntak, Enrico Parulian. "PENGUJIAN ADA TIDAKNYA PENYALAHGUNAAN WEWENANG MENURUT UNDANG-UNDANG ADMINISTRASI PEMERINTAHAN / EXAMINATION TO DETERMINE THE PRESENCE OR ABSENCE OF ABUSE OF AUTHORITY ACCORDING TO GOVERNMENT ADMINISTRATION LAW." Jurnal Hukum Dan Peradilan 7, no. 2 (July 29, 2018): 237. https://doi.org/10.25216/jhp.7.2.2018.237-262.

Wibowo, Ari. "PENENTUAN KRITERIA UNSUR PENYALAHGUNAAN WEWENANG DALAM PERKARA TINDAK PIDANA KORUPSI (STUDI PUTUSAN PENGADILAN)." $\quad$ Yuridis $7, \quad$ no. $1 \quad$ (2020): $120-48$. https://core.ac.uk/download/pdf/327205589.pdf.

Yedi Purwanto, and Ridwan Fauzy. "ANALISIS TERHADAP HUKUM ISLAM DAN HUKUM POSITIF DALAM PEMBERANTASAN KORUPSI DI INDONESIA” 15, no. 2 (2017): 127-40. http://jurnal.upi.edu/file/05_Analisis_Terhadap_Hukum_Islam__Yedi_P1.pdf.

\section{Regulations}

Law Number 5 of 1986 concerning State Administrative Courts

Law Number 31 of 1999 in conjunction with Law Number 20 of 2001 concerning Eradication of Corruption Crimes

Law Number 13 Year 2003 Concerning State Finances

Law Number 30 of 2014 concerning Government Administration (GA Law)

Government Regulation Number 4 of 2015 concerning Guidelines for Procedures in the Assessment of Elements of Abuse of Authority (BN Number 1267 of 2015), Article 3. 


\section{Decisions}

Decision of the State Administrative Court Number 250/P/PW/2015/PTUN-JKT

Decision of the State Administrative Court Number 257/P/PW/2015/PTUN-JKT

Decision of the State Administrative Court Number 15/P/PW/2016/PTUN.PLK

Central Jakarta District Court Decision Number 93/Pid.Sus/TPK/2015/PN.Jkt.Pst

Decision of the High Court of the Special District of Jakarta Nomor 25/PID/TPK/2016/PT.DKI

Decision of the Supreme Court Number 302 PK/Pid.Sus/2018

Decision of the Palangka Raya District Court Number 40/Pid.Sus-TPK/2016/PN.Plk.

Decision of the High Court of Palangka Raya Number 1/Pid.Sus-TPK/2016/PT.Plk.

Decision of the Supreme Court 1055/K/Pid.Sus/2017. 9

\section{E. Internet}

2017. Justicia Law Firm. 29 April. Accessed 28 January 2021. http://justitialawfirm.or.id/2017/04/29/menyalahgunakan-kewenangan-dalam-tindakpidana-korupsi-dan-penyalahgunaan-wewenang-pada-hukum-administrasi/ Justicia Law Firm. 